\title{
Slums in Semi-Arid Regions: An Analysis of the Vulnerability and Coping Strategies of Selected Neighbourhoods in the Wa Municipality, Ghana
}

\author{
Issaka Kanton Osumanu1 ${ }^{*}$, Abubakari Ahmed², Raqib Abu Salia3 ${ }^{3}$ Abdul-Rahim Abdulai4, \\ Alfred Dongzagla ${ }^{5}$ \\ ${ }^{1}$ Department of Environment and Resource Studies, University for Development Studies, Tamale, Ghana \\ ${ }^{2}$ Institute for Environment and Sanitation Studies, University of Ghana, Accra, Ghana \\ ${ }^{3}$ Department of Development Studies, University for Development Studies, Tamale, Ghana \\ ${ }^{4}$ Institute of Local Government Studies, Accra, Ghana \\ ${ }^{5}$ Department of Planning and Management, University for Development Studies, Tamale, Ghana \\ Email: *kosumanu@uds.edu.gh
}

Received 20 November 2015; accepted 6 December 2015; published 9 December 2015

Copyright (C) 2015 by authors and Scientific Research Publishing Inc.

This work is licensed under the Creative Commons Attribution International License (CC BY).

http://creativecommons.org/licenses/by/4.0/

(c) (i) Open Access

\section{Abstract}

This study investigates the vulnerability of slum dwellers and the resulting coping strategies of three spontaneous neighbourhoods in the Wa Municipality of Ghana. The study relied on mixed methods with questionnaire administration as its main data collection technique focusing on the social, economic and environmental dimensions of slums. It found that, even among slum close neighbourhoods, the overall degree of vulnerability varies thereby representing a potential source of dynamic resource for small cites. Slums selected are less vulnerable to environmental issues than socioeconomic dimensions. The sustainability challenges therefore lie within the improvement of social and economic choices. An identification of place based capabilities, opportunities and localised constraints could serve as basis for designing of an appropriate planned intervention.

\section{Keywords}

Coping Strategies, Ghana, Semi-Arid, Slums, Sustainability, Urbanization, Vulnerability

\footnotetext{
${ }^{*}$ Corresponding author.
}

How to cite this paper: Osumanu, I. K., Ahmed, A., Salia, R. A., Abdulai, A.-R., \& Dongzagla, A. (2015). Slums in Semi-Arid Regions: An Analysis of the Vulnerability and Coping Strategies of Selected Neighbourhoods in the Wa Municipality, Ghana. Current Urban Studies, 3, 331-347. http://dx.doi.org/10.4236/cus.2015.34027 


\section{Introduction}

UN-Habitat (2012) approximated that, between 2010 and 2015, an average of around 200,000 people will be added to the world's urban population each day. Worth noting is that $91 \%$ of this daily increase (or 183,000) is expected to take place in developing countries (UN-Habitat, 2012). Approximately 13\% of the urban population in developing countries lives in sub-Saharan Africa but the sub-region hosts about 25\% of slum population of developing countries (UN-Habitat, 2009). Again, over 60\% of urban population in sub-Saharan Africa lives in slums and unplanned neighborhoods (Fox, 2014). The annual slum and urban intensification rates are highest in sub-Saharan Africa and the proliferation can be seen as a consequence of disjointed modernization (Fox, 2014). The fundamental ingredient to the multidimensional structural transformation of low-income rural societies to urban centres is to undergo modernization through the flow of ideas (Lucas, 2004). However, in Africa the trend is characterized by rapid urban growth occurring in the face of economic stagnation, poor governance, rising unemployment, poor agricultural performance, financially weak municipal authorities and the absence of coherent urban planning policy (Cheru, 2005; Annez et al., 2010). Under such conditions, including state retrenchment, currency devaluation, and structural adjustment, “... rapid urban growth has been an inevitable recipe for the mass production of slums” (Davis, 2004: p. 11). Slum is the recognizable frame through which the cities of the global South are perceived and understood (Nuttall \& Mbembe, 2005).

Slum neighborhoods are often associated with an unsustainable informal sector with human lifestyles and consumerism that lead to the modification of city landscapes, urban systems, loss of biodiversity, climate change, urbanization of poverty and lack of social services (Grimm et al., 2008; Stren \& Halfani, 2001; World Bank, 2009; Seto et al., 2012; Weisz \& Steinberger, 2010). The drive towards sustainability of neighborhoods has recognized the role of urban planning, yet, most urbanization processes and urban forms are considered unsustainable (Desai, 2008; Alberti et al., 2007; Wu, 2009; Williams et al., 2010; Jones et al., 2009). Most have attributed it to mass failure of urban governance (Faguet, 2012; Gulyani \& Talukdar, 2008), others comprehend it within the framework of institutional crisis (UN-Habitat, 2003; World Bank, 2009) and yet some traced it to colonialism and proliferation of neoliberal policies (Fox, 2014; Lange 2004; Davis, 2006). The resultant effects are observed in the wide spread of urban vulnerability, poverty, and the struggle for sustainable livelihoods.

Slum dwellers in the midst of their precarious socio-economic and environmental situations, adapt various coping strategies so as to earn a living. In most cases, coping strategies adopted by slum dealers are unsustainable, in that, they are illegal and/or short-term measures (Essamuah \& Tonah, 2004). In quest for urban sustainability, understanding the knowledge on the coping strategies of slum dwellers, particularly within various environmental, social and economic contexts can contribute tremendously to the design or redesign of projects. However, fewer studies have explored holistically, social, economic and environmental vulnerabilities and coping strategies that slum dwellers adopt in the face of their multifaceted urban challenges, particularly in semi-arid regions.

To the best of our knowledge, this paper is among the few that address sustainability issues of small or secondary cities in semi arid regions of sub-Saharan Africa from the perspective of slums. Contextualising slums within the purview of semi-arid regions are scarce. Out of 12 cities considered as having weak urban prosperity in the World Cities Report 2012/2013 (UN-Habitat, 2012), nine of them fall under arid and semi-arid regions. In another perspective, 10 of the 12 most drought-vulnerable countries are located in Africa (UN-Habitat, 2014). Empirical and theoretical contributions to semi arid literature have focused mainly, but not exclusively, on rural vulnerability, climate change, agriculture, rural livelihood, pastoralism and peasantry (Bird \& Shepherd, 2003; Slegers, 2008; Biamah, 2005; Lioubimtseva \& Henebry, 2009; Lioubimtseva et al., 2008; Tsegaye et al., 2013; Berhanu et al., 2007; Tsegaye et al., 2009; Frost et al., 2007; Ulrich et al., 2012). There are fewer contributions from the perspective of slums in small cities of semi arid regions of sub-Saharan Africa (e.g. Thys et al., 2005; Deelstra \& Girardet, 2000). Whereas African cities have high urban risks, institutional fragility, political turbulences, governance failures and high proportion of slums (UN-Habitat, 2014), the environmental adversaries of those in arid and semi-arid regions bring additional burdens, deepened vulnerability and livelihood challenges.

A focus on sustainability challenges and coping strategies represents a particular lens through which competing urban challenges can be analysed. There is a noteworthy absence of studies on vulnerability and sustainability related to the urban context of semi-arid interior cities in West Africa. Most recent studies on the relationship between urban sustainability and vulnerability in West Africa have focused on a few large coastal cities like Dakar, Accra, and Lagos (e.g. Ajibade \& McBean, 2014; Appeaning Addo, 2013; Essamuah \& Tonah, 2004). With the adoption of a recent national urban policy by Ghana, there are directives on management, climate 
change adaptation and mitigation in coastal cities and forest belt (Ghana, 2012), yet the policy failed to give due consideration to semi-arid cities. The lack of an urban focus in the semi-arid region is an important gap given the growing importance that smaller and secondary cities will play in the urban growth trajectories in the next several decades (de Noronha \& Vaz, 2015). This research therefore seeks to demonstrate the vulnerability of slum dwellers under the three pillars of sustainable development, and the coping strategies within close neighbourhoods in the Wa Municipality of Ghana.

\section{Slums: A Literature Review}

It is difficult to unearth a general definition for "slum" as a concept, construct, term, or even a theory. While crisis and catastrophe justifies the theoretical exploration of slums, there is an equally epistemological discussion focusing on the persistence of these forms of habitation through which marginalized populations are substantiating their presence in cities across the world (see Simone, 2004, 2010). With its emergence in the 1820s, the poorest quality housing and the most unhygienic conditions characterized slums (Lemma, 2005). In the $19^{\text {th }}$ century, slum was seen as any street, alley or court that is crowded in a town or city (Friedman, 1968). Others have viewed slums as "place of slumber" (Dennis, 2004: p. 235), "home of the poor and stranger" (Stokes, 1962: p. 188) and "synonymous with racket" (Prunty, 1998: p. 2). Urban slums are generally classified as one of the world's most life threatening settlements (Pietro et al., 2005). Some treat slum as a systematic and orderly organized area located in an environmentally deteriorated place (Desai \& Devadas, 1990). The term "slum" not only suggests indecent and miserable living conditions but also implies other important aspects such as informality (World Bank/UNCHS, 2000). Though there exist ongoing epistemological discussion regarding slum, people living under these conditions are often called "slum dwellers" (d'Cruz \& Satterthwaite, 2005).

Rapid urbanization and globalization created the necessary preconditions for slums to be viewed as "touristic transit" with obvious examples in Soweto town of Johannesburg and Rocinha fevela of Rio de Janeiro (FreireMedeiros, 2009). Previous studies on the emergence of slums have raised many issues such as social networking, housing failure, governance, migration, globalization, formality, territorial logic of neoliberalism, spatial dispossession, zones of exceptions, right to produce and use space as well as right to city (Obudho \& Aduwo, 1989; Lefebvre, 1996; Smith, 1996; Ali \& Toran, 2004; Davis, 2004; Harvey, 2005; Nuttall \& Mbembe, 2005; Ong, 2006; Choguill, 2007; Akter, 2008; Harvey, 2008; Annez et al., 2010; Butala et al., 2010; Arimah, 2011; Roy, 2011; Firdaus, 2012). Although these studies have fostered an understanding of the political, economic, social and historical factors associated with slums, there exist no consensus on the definition of slum and fixed solutions. New perspectives call for redefinition of slums through the lens of environment, social and economic factors but context specific (Pugalis et al., 2014; Khalifa, 2011). Khalifa (2011) recommends two definitions "unplanned" and "unsafe". There are possibilities of where institutional and implementation failures can make a planned area unsafe.

UN-Habitat defines slum as "an area that has, to various degrees, these features (limited to the physical and legal features of the settlement, and neglecting the complicated collective dimensions): inadequate access to safe and secure water, insufficient sanitation and other related infrastructure, poor structural quality of houses, congestion, and insecure residential status" (UN-Habitat, 2003: p. 12). These features suggest ill health, diffusion of diseases, infant mortality, juvenile delinquency and crime that injuriously affect the whole area, constituting a threat to public health, welfare, safety and morals of the residents. Such settlements have emerged due to the inability of conventional housing markets to cope with the demand created by rapid urbanization (Johnston et al., 2000; Clark, 2003). In order to achieve target 7d of the MDGs, the UN-Habitat (2003) adopted five indicators used in defining slum households that are quantifiable. The UN Habitat's definition does not differentiate between or prioritize the five shelter deprivations according to the risk posed to peoples' lives, types of shelter deprivation and the degree or magnitude of the deprivations (Khalifa, 2011). The UN-Habitat's measurement of slum neglects local realities, as the severity might not be in numbers of households affected but the depth of the lack of access to social services. Secondly, slums might not necessarily occur in only urban areas as peri-urban development without proper social services and facilities could be classified as slums. It has also failed to recognise that some slums are formal and others informal but gives extreme focus on legality and vulnerability (Alemayehu, 2008; Pugalis et al., 2014). The UN-Habitat's (2003) definition falls within the purview of utilitarian ideology in which action takes place when greater numbers are affected. For instance, Cities Alliance's choice of measurement of progress is based on the proportion of people with access to improved sanitation and 
those with access to secure tenure (World Bank/UNCHS, 2000). If these two are the benchmarks, the rationale as to why the word "slum" is used makes the term a construct (Ahmed, 2014). Cruz (2005) refers to it as a political equator.

Bolay (2006) narrates the position regarding the creation of slums. According to him, rapid urbanization while paving the way for prosperity has also been responsible for the creation of slums, degeneration of human society and it is the base for its enhancing character. In the present day world, especially in developing countries, the growth of slums is usually parallel to the growth of urbanization. In the Planet of Slum, Davis (2006) attributes the rapid emergence of slums to capitalism and neoliberal policies that allowed for mass migration during industrialisation in developing countries. Mike Davis argues that urbanisation and industrialisation coupled with rural poverty are the leading causes of the emergence of slums. Contrary to this opinion, Angotti (2006) is sceptical of rural poverty as a cause of mass migration, since rural poverty is better off than urban poverty. A recent review by Fox (2014) argues that correlation of incidence does not explain convincingly the scale and diversity of slums. The variations in colonial investment in Africa as well as the institutional developments correlate with contemporary incidence of slums (Fox, 2014).

Slums in African cities develop because of a combination of rapid rural-to-urban migration, increasing urban poverty and inequality (UN-Habitat, 2003), marginalization of poor neighbourhoods and the urban poor's lack of access to affordable land for housing (Bolay, 2006). Insufficient investment in new low-income housing and poor maintenance of existing housing and inconsistent urban planning policies are also factors (Cheru, 2005). The failure of urban governance is seen as a key factor that leads to slum development (Fox, 2014). This is a reflection of the general failure in many African countries, whether welfare-oriented or market-based. A major reason for the existence and continuing growth of slums in African cities is the lack of effective policies on housing and urban problems (Berger, 2006).

In Ghana some scholars attribute the emergence of slums to the structural adjustment programme that created the preconditions for urbanisation of cities (Konadu-Agyemang, 2001). Some attribute it to government failure to profile and private sector failure to provide adequate housing, secured tenures and reduce rural-urban migration (Mahama \& Adarkwah, 2006; Owusu et al., 2008; Owusu, 2008; Nsiah-Gyabaah, 2009; Owusu, 2010). Like other slum neighbourhoods in developing countries, slum dwellers in Ghana adopt a multiple of strategies to cope with livelihood. Essamuah and Tonah (2004) outline detail strategies of coping strategies in their analysis of the coping strategies of the urban poor in Nima, a slum neighbourhood in Accra. Policy measures aimed at addressing slums since 1950 chronologically include laissez-Faire Attitude (1950-1960s), Site and Service Schemes (1970s), Upgrading Strategies (1980s), Security of Tenure (1990s) and Cities without Slums (2000s) (Sietchiping, 2005). Until recent time 2012, Ghana did not have an urban policy. In 2012, the first national urban policy was adopted as a renewed commitment to the urban challenges in Ghana. In 2010, about $40 \%$ of urban population live in slum and the figure is extrapolated to 6,427,000 people by the end of 2017 (Ahmed, 2014). If these are to be successfully supplied, approximately 3123 new rooms must be completed in every day from now until 2017 when the policy action plan will end.

\section{Methodology}

\subsection{Study Area}

The Wa Municipality is one of the eleven districts that make up the Upper West Region of Ghana. It shares administrative boundaries with Nadowli District to the North; the Wa East District to the East and South; and Wa West District to the West and South. It lies within latitudes $1^{\circ} 40^{\prime} \mathrm{N}$ to $2^{\circ} 45^{\prime} \mathrm{N}$ and longitudes $9^{\circ} 32^{\prime}$ to $10^{\circ} 20^{\prime} \mathrm{W}$ (Figure 1). In 2010, the total population of the municipality was 127,284 (Ghana Statistical Service, 2012). Research on the level of aridity is scarce, but generally, the entire Upper West Region including the Wa Municipality is located in the tropical continental or interior savannah climate zone (Dickson \& Benneh, 1988; Walker, 1962; Duadze, 2004), which is a type of semi-arid climate (Walker, 1962). Wa is characterized by alternating dry and wet seasons with tropical continental air, tropical maritime and Equatorial Easterly masses (Dickson \& Benneh, 1988). Secondary data sourced from the University of Oklahoma Rain Watch indicates that temperatures can rise as high as $40^{\circ} \mathrm{C}$ in the months of February and March (see Figure 2 and Figure 3). Wa Municipality has its capital as Wa, a secondary town which also serves as the regional capital of the Upper West Region. It has a landmass area of approximately $234.74 \mathrm{~km}^{2}$, which is about $6.4 \%$ of the region. 
WA TOWNSHIP WITH STUDY NEIBOURHOODS

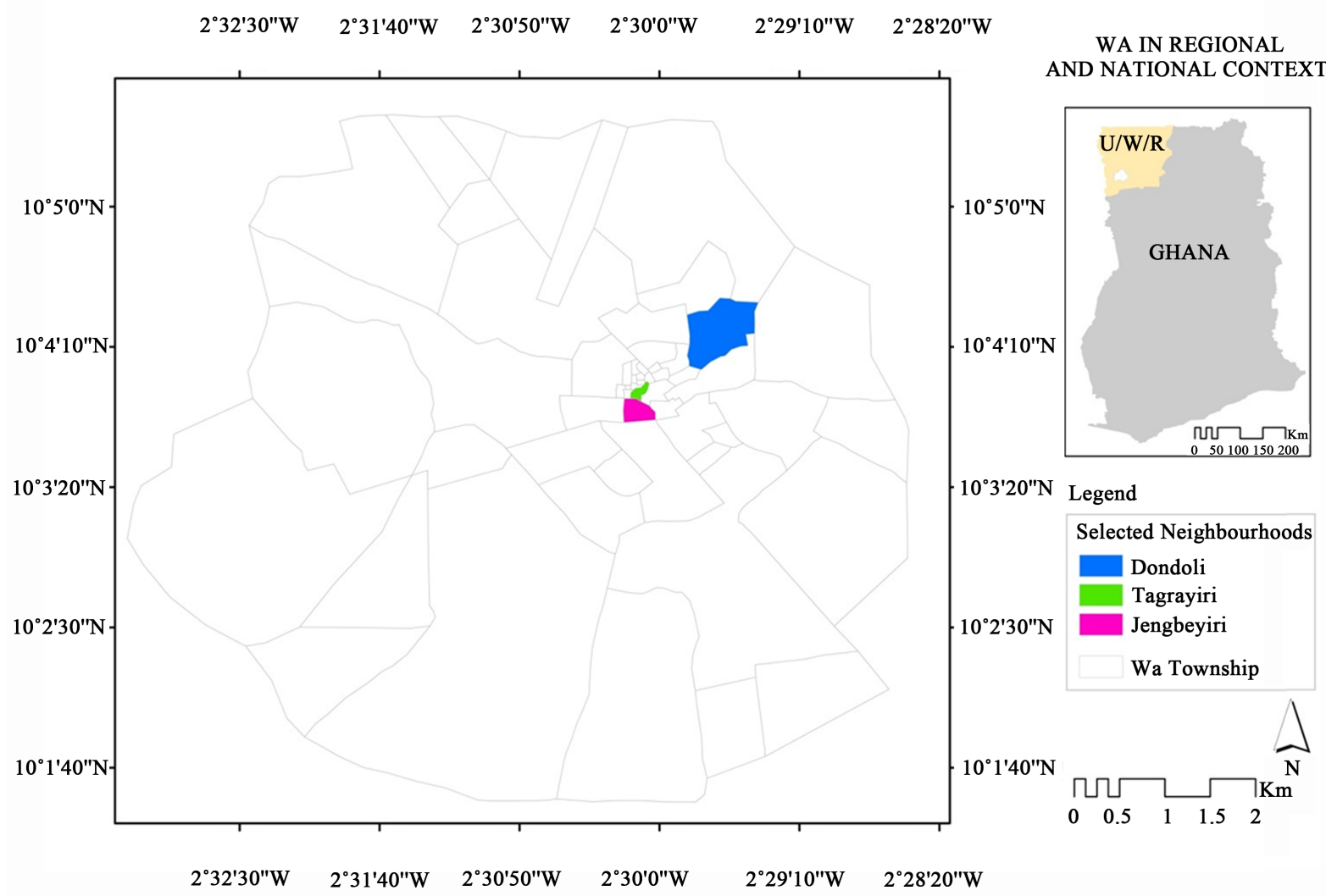

Figure 1. Location of study area.

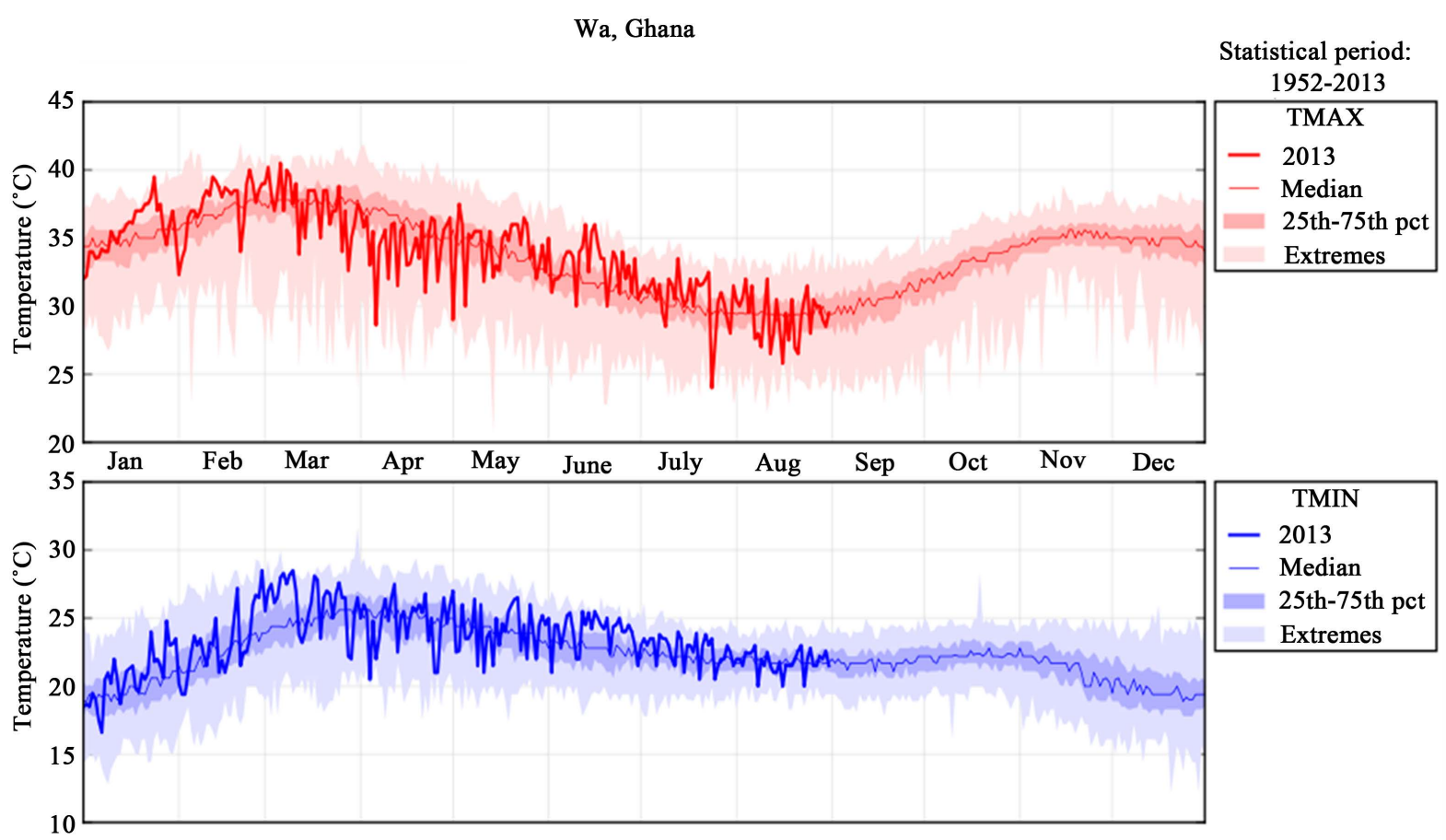

Figure 2. Time series of monthly temperature of Wa Township, 2013. Source: Rain Watch (2014). 


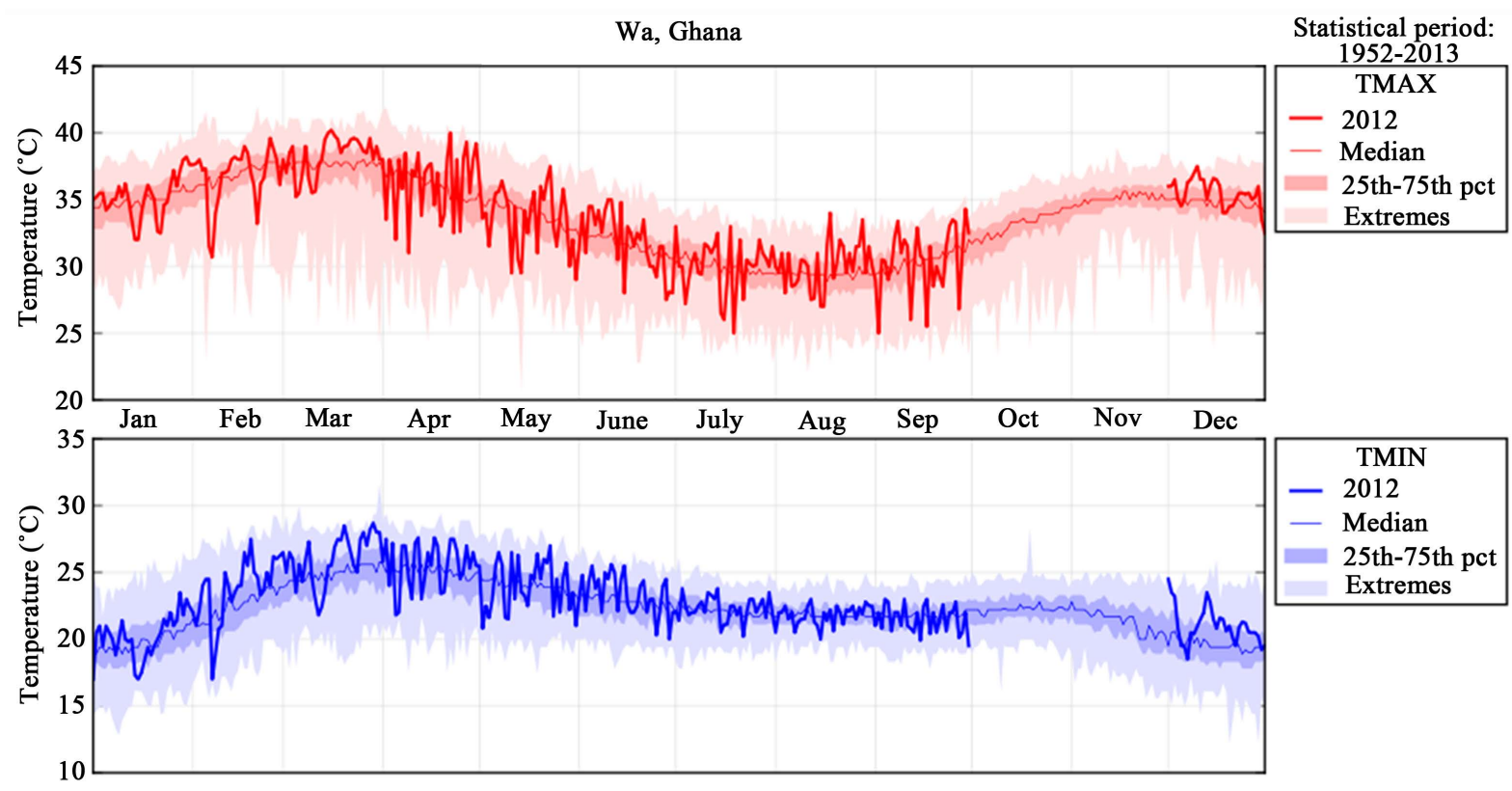

Figure 3. Time series of monthly temperature of Wa Township, 2012. Source: Rain Watch (2014).

The municipality falls within a semi arid region of Ghana where everything seems to be a paradox. More than $80 \%$ of the population is engaged in agriculture, yet one in five is food insecure and one in nine children die of malnutrition before the age of five (Nyantakyi-Frimpong \& Bezner Kerr, 2015; Ghana Statistical Service, 2013; Biederlack \& Rivers, 2009). This is a region where food crop farmers or subsistence households are the poorest of the poor and suffer most in terms of malnutrition (Nyantakyi-Frimpong \& Bezner Kerr, 2015; Biederlack \& Rivers, 2009). Literature has situated the reasons for these predicaments under the ongoing discourse of geographic inequality (Nyantakyi-Frimpong \& Bezner Kerr, 2015). Common empirical reasons include drought, colonialism, and the neoliberal development policies (Nyantakyi-Frimpong \& Bezner Kerr, 2015; NyantakyiFrimpong \& Bezner Kerr, 2014; Rademacher-Schulz et al., 2014; Yaro, 2013; Songsore, 2003).

The Northern Territories of Ghana (now Upper West, Upper East and Northern Regions) which is generally arid and landlocked under the British rule were annexed until 1901 because of limited avenue for export and mineral wealth (Songsore, 2003). The Territories were rather used as source of labour to the south and people from the north have to move to south to work and pay their colonial taxes. This was the genesis of the current persistent migration between the north and south of Ghana even in modern times (Rademacher-Schulz et al., 2014). Post-colonail policies also adopted regional biases left over the colonial masters, which reinforced regional inequalities as the north was neglected from government investment because of it natural resource endowments, limited transportation and market (Songsore, 2003; Yaro, 2013). The effects are still manifested in the semi arid region of Ghana and Fox's (2014) tracing of the emergence of slum to colonialism is of relevance to this area.

It has 51 neighbourhoods forming the Wa Township. Jengbayiri, Dondoli and Tagirayiri, which are among the low class residential areas, were selected for various reasons. First, these neighbourhoods either shares boundary with the Central Business District (CBD) or are located in proximity to it, and thus exhibits fundamental characteristics of low class residential areas. Second, Jengbayiri, Dondoli and Tagirayiri can best be described as slum settlements, in that, they are characterized by unplanned developments, high poverty levels, poor access to social services and infrastructure, poor housing conditions, among others. Third, the selected neighbourhoods have high population density and unique land tenure characteristics (see Table 1) given that some inhabitants are early settlers since the $20^{\text {th }}$ century with secured land tenure (Wilks, 1989).

\subsection{Methods}

In this study, primary and secondary data are both integrated. The study includes both qualitative and quantitative materials gathered from the administration of questionnaires, literature review and direct observations. 
Table 1. Population and land tenure characteristics of selected neighbourhoods.

\begin{tabular}{ccccc}
\hline Neighbourhood & Population & Area (Hectares) & Density (/ha) & Land tenure \\
\hline Dondoli & 2062 & 8.6 & 240 & Early settlers \\
Tagirayiri & 1531 & 2.1 & 729 & Early settlers \\
Jengbayiri & 1586 & 2.9 & 547 & Early settlers \\
\hline
\end{tabular}

Through an urban sustainability lens, data was collected, using questionnaires, on three dimensions namely: social, economic and environmental. A semi-structured questionnaire was used to collect data at the various selected communities. An initial visit to the selected areas was undertaken to introduce and familiarize with the inhabitants as well as seek their consent for the study. In all 371 heads of households responded to the questionnaire administration. In the selected areas, households were questioned on the coping mechanisms and frequency of adopting a particular strategy. Observation was used to assess the evidence on the ground on the ground through field visits. For instance, observations were made of how neighbourhoods related to livelihood activities.

Ten of the surveyed placed-based vulnerability criteria were considered for vulnerability analysis. These broadly include social (literacy rate and service availability), economic (consumption and income) and environmental (living space, housing durability, water, bath house, toilet facility and refuse disposal). To understand the service availability in neighbourhoods, a settlement functional matrix was first developed using a scalogram analysis. The selected areas are ranked using centrality scores obtained based on population, access and availability of social services. A Spatial Multi-Criteria Evaluation (SMCE) module in ILWIS (Integrated Land and Water Information Management System) was used to aggregate the effects of the criteria for each neighbourhood to obtain a graduated colour map with values showing the overall vulnerability of each neighbourhood and also for the three broad sustainability dimensions—social, economic and environmental.

\section{Results}

\subsection{Demographic and Socio-Economic Characteristics}

There are some significant variations, especially in income, expenditure, literacy and household headship, among slum neighbourhoods. In terms of female headship, Tagirayiri has more than the other selected neighbourhoods. This research shows that in female-headed households, income levels are higher as well as expenditure and literacy levels than in male headed households. Few female-headed households are living in temporary structures for the selected areas considered. In the urban area of the semi-arid region, most people $(42 \%$ of respondents) are into trading and other than agricultural based livelihood activities. The strategic location of the centre makes it a hub and a transit point to and from neighbouring country—Burkina Faso. The slum areas are predominantly Muslims with high levels of polygamy and, instead of men taking care of the family, the wives are left to work hard and compete among themselves for favours from their husbands (Bashiru, 2012). Masinde (2014) recalls this in the Kenyan slums that most males are now abandoning their responsibilities to their wives. Polygamy in itself has become a coping strategy for these predominantly Muslim slum communities studied.

\subsection{Vulnerability and Placed-Based Context}

Approaching slums through a placed-based lens (Table 2), shows the various placed-based characteristics. The placed features are grouped under themes of social, environmental and economic dimensions with summary analysis. Socially, slum dwellers of the selected areas have long years of placed attachment with their environments (over 68\% lived there for the past 16 years) with secured land tenures as early settlers. This contradicts with the stereotype that slums are places for the strangers (e.g. Stokes, 1962; Prunty, 1998). Whereas there is a surge of new entrants, they mostly come on the basis of social networks. There are also observed low levels of engagement with organized clubs (social and sports clubs) as well as less preference for civil organizations for reasons of corruption and bureaucracies. These findings are similar to Pugalis et al. (2014) in the case of Kpirikpiri-Nigeria. Economically, the conditions reported (see Table 2) in terms of proportion of people in the informal sector, unskilled, unemployed and literacy are similar to most studies on slums in developing countries. 
Table 2. Selected placed-based characteristics of heads of households.

\begin{tabular}{|c|c|c|c|}
\hline Dimensions/criteria & Categories/Indicators & $\begin{array}{l}\text { Respondents } \\
\text { /response }\end{array}$ & Headline Analysis \\
\hline $\begin{array}{c}\text { Social } \\
\text { Length of Residence }\end{array}$ & $\begin{array}{l}\text { Less than } 1 \text { year } \\
1-5 \text { years } \\
6-10 \\
11-15 \text { years } \\
\text { Over } 16 \text { year }\end{array}$ & $\begin{array}{c}4 \% \\
6 \% \\
0 \% \\
22 \% \\
68 \%\end{array}$ & $\begin{array}{l}\text { New entrants consist of about } 10 \% \text { (less than } 5 \text { years) } \\
\text { which is an indication of continuous migration thereby } \\
\text { putting pressure on existing facilities. However, } \\
\text { long term experience of their living landscape is } \\
\text { important in developing social capital in the slums }\end{array}$ \\
\hline $\begin{array}{l}\text { Reasons for } \\
\text { Living there }\end{array}$ & $\begin{array}{l}\text { Work } \\
\text { Family/Grew up there } \\
\text { Friends } \\
\text { Studies }\end{array}$ & $\begin{array}{c}7 \% \\
82 \% \\
11 \% \\
0 \%\end{array}$ & $\begin{array}{l}\text { Many of those who stay there for work purposes } \\
\text { are mostly new immigrants with small businesses within } \\
\text { the periphery. Social tiers and networks also increase } \\
\text { the rate of migration as 3\% came based on friendship. }\end{array}$ \\
\hline $\begin{array}{l}\text { Membership of } \\
\text { associations }\end{array}$ & $\begin{array}{l}\text { Religious associations } \\
\text { Social clubs } \\
\text { Sports clubs } \\
\text { Community associations } \\
\text { Trade unions } \\
\text { Political parties } \\
\text { Welfare groups }\end{array}$ & $\begin{array}{c}9 \% \\
8 \% \\
0 \% \\
12 \% \\
19 \% \\
50 \% \\
2 \%\end{array}$ & $\begin{array}{l}\text { Slum dwellers are able to organise collective } \\
\text { social actions through various movements and } \\
\text { political agencies in pursuit of rational adaptive } \\
\text { responses to conflicts of interest but political } \\
\text { fractionalization limits collective actions. } \\
\text { Dwellers see provision of welfare as a } \\
\text { responsibility of political parties they vote for. } \\
\text { Slums are hubs of votes }\end{array}$ \\
\hline Thrust in Authorities & $\begin{array}{l}\text { Courts } \\
\text { Government agencies } \\
\text { Local authorities } \\
\text { Traditional authorities }\end{array}$ & $\begin{array}{l}37 \% \\
9 \% \\
23 \% \\
31 \%\end{array}$ & $\begin{array}{c}\text { Many dwellers do not prefer civil } \\
\text { organizations for reasons of corruption } \\
\text { and bureaucracies } \\
\text { undermine the performance of social capital. }\end{array}$ \\
\hline $\begin{array}{c}\text { Security of } \\
\text { Housing Tenure }\end{array}$ & $\begin{array}{c}\text { Free tenants } \\
\text { Renters } \\
\text { Self-owned houses }\end{array}$ & $\begin{array}{l}24 \% \\
41 \% \\
35 \%\end{array}$ & $\begin{array}{l}\text { With an established university in the town, } \\
\text { many houses are being renovated to rent out by } \\
\text { landlords. Dwellers who are not competitive } \\
\text { are priced out of the market }\end{array}$ \\
\hline Literacy & $\%$ that can read and write & $27 \%$ & $\begin{array}{l}\text { The finding confirms the general } \\
\text { assertion that many slum dwellers lack } \\
\text { formal education } \\
\text { and formal skills, especially in Africa. }\end{array}$ \\
\hline $\begin{array}{l}\text { Economic } \\
\text { Employment }\end{array}$ & $\begin{array}{l}\text { Formally employed } \\
\text { Informally employed } \\
\text { Unemployed } \\
\text { Retired }\end{array}$ & $\begin{array}{c}15 \% \\
52 \% \\
31 \% \\
2 \%\end{array}$ & $\begin{array}{l}\text { The informal sector remains the largest } \\
\text { as well as the unemployed reflecting the } \\
\text { lack of skills and levels of vulnerability } \\
\text { among slum dwellers. }\end{array}$ \\
\hline Income & $\begin{array}{l}\text { Average monthly } \\
\text { household income }\end{array}$ & US\$102.87. & $\begin{array}{l}\text { Income differentials translate into } \\
\text { diverse consumption patterns of }\end{array}$ \\
\hline Consumption & $\begin{array}{l}\text { Average monthly } \\
\text { household expenditure }\end{array}$ & US\$52.86. & $\begin{array}{l}\text { aiverse consumption patterns of } \\
\text { which there are potentials for savings. }\end{array}$ \\
\hline Skills & $\begin{array}{c}\text { Teaching } \\
\text { Technicians } \\
\text { Trading } \\
\text { Carpentry and joinery } \\
\text { Hair dressing } \\
\text { Entertainment } \\
\text { Catering } \\
\text { Urban agriculture } \\
\text { Unskilled }\end{array}$ & $\begin{array}{c}6 \% \\
9 \% \\
42 \% \\
1 \% \\
5 \% \\
1 \% \\
2 \% \\
12 \% \\
22 \%\end{array}$ & $\begin{array}{l}\text { The levels of exposure to risks are reinforced by the } \\
\text { lack of skills and seasonality of trading that some } \\
\text { undertake. Urban agriculture remains a better } \\
\text { alternative to cope with the aridity of the environment. } \\
\text { However, the diversity in skills could be a source of } \\
\text { dynamic resource to urban prosperity, if enhanced, } \\
\text { as well as a source of urban resilience. }\end{array}$ \\
\hline Rent & Average annual rent & $\begin{array}{l}\text { GH\$220.00 } \\
\text { (US\$67) }\end{array}$ & $\begin{array}{l}\text { Over } 50 \% \text { of households spend over } 50 \% \\
\text { of their income on rent which goes } \\
\text { contrary to the UN recommendation of } 30 \% \text {. }\end{array}$ \\
\hline $\begin{array}{c}\text { Environmental } \\
\text { Durability of Houses }\end{array}$ & Housing in temporary structures & $21 \%$ & $\begin{array}{l}21 \% \text { of the houses are built with sub-standard } \\
\text { materials, such as mud and woods. This is a reflection } \\
\text { of the inability of government and the private } \\
\text { sector to build for the urban poor. }\end{array}$ \\
\hline
\end{tabular}




\section{Continued}

Living Space

Water source

Access to toilet
Average household size Average room occupancy rate

Pipe connection Boreholes

Vendors

Toilet in-house

Public toilets

Open defecation
$5.7(6)$

3.5

$66.1 \%$

$4.1 \%$

$29.8 \%$
The room occupancy rate is greater than the

UN-Habitat recommendation of 3. It is a reflection of lack of planned space to populate.

Majority have access to potable water though more than $11 \%$ spend over $10 \%$ of their income on water, which is higher as recommended by UN.

Self-perpetuating cultures of free range and open disposal of waste promote self-destructive behaviours that reinforce poverty in the slums. However, they are coping strategies in themselves given the barriers of inclusive development and neglect by local authorities in addressing the structural causes of poverty. Once denied, the poor are not to blame as impediments.

Environmentally, high room occupancy rates, lack of improved sanitation and poor housing conditions are similar to other studies on slums. However, over $29 \%$ of the households do not have access to potable water and rely on vendors who are irregular in supply but charge higher prices. Those who depend on pipe connections are particularly vulnerable to irregular water flow and the long distance they cover to have access to pipe water. The critical changes of groundwater discharge in semi-arid regions (see Scanlon et al., 2006) affects access to water in the selected areas. Access to surface water in the Wa Municipality is limited because of the low levels of precipitation and existing water suppliers (Ghana Water Company, vendors) rely on groundwater (see Figure 2 and Figure 3 for rainfall). The over $12 \%$ of households depending on urban and peri-urban agriculture are also vulnerable to the climate variability of their environment.

\subsection{Variations in Vulnerability among Slum Neighbourhoods}

Area/neighbourhood based analysis of vulnerability can be used to identify spatial concentration of particular population groups with different policy/project requirements (Pacione, 2005). Table 3 contains details of the measurement and effects of each criterion across neighbourhoods. The variations in access to social services are also shown in Table 4. The standard deviation ranges from 0.6 for living space to as high as 604.8 for service availability. The variation in the effects of neighbourhoods for each criterion suggests that the level of vulnerability of slum neighbourhoods, even at criteria level, varies.

In the context of this study, a composite index of zero (0) represents high vulnerability while one (1) represents less vulnerability (see legend in Figure 4). The results reveal a variation in the overall vulnerability index of the three slum neighbourhoods (Tagirayiri, Dondoli and Jengbeyir). The overall vulnerability indices of the neighbourhoods are $0.88,0.75$ and 0.70 for Tagirayiri, Dondoli and Jengbeyiri respectively (Figure 4). This implies that among the three neighbourhoods, Tagrayiri is the least vulnerable, followed by Dondoli and lastly Jengbeyir. The vulnerability indices of the three neighbourhoods yield a standard deviation of 0.09 , implying that the degree of vulnerability of the three neighbourhoods do not vary significantly. In reference to the three sustainability dimensions, Tagrayiri is equally the least economically and socially vulnerable (see Figure 5). However, concerning the environmental dimension, Tagrayiri is the second most vulnerable neighbourhood (see Figure 4 and Figure 5). In general terms, all the selected areas are less environmentally vulnerable relative to social and economic vulnerabilities. This is because there are fewer socioeconomic opportunities in the area. Agriculture is limited because of the erratic rainfall patterns and businesses are few. Between social and economic vulnerabilities, there are more social vulnerabilities attributable to the limited availability and access to basic social services such as education and health shown in Table 4. The sustainability challenges therefore lies within the improvement of social and economic choices.

\subsection{Households Coping Strategies}

There is high level of livelihood diversification among people in Dondoli and Jengbayiri but less in Tagirayiri because the high female household headship comes with significant savings for such households. Tagirayiri also is less vulnerable as shown in Figure 4 and Figure 5. A female respondent in Dondoli recalls the volatility: 


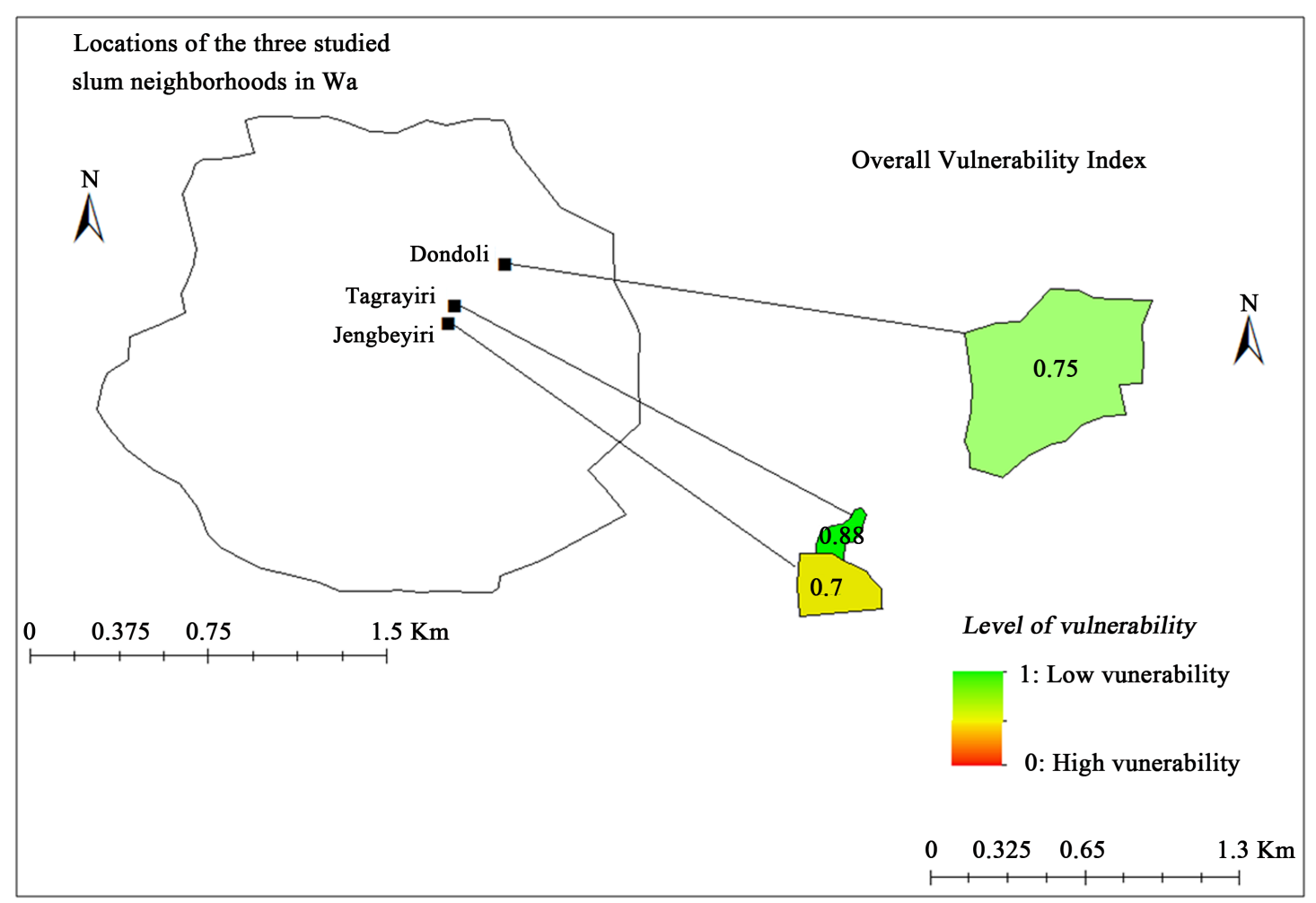

Figure 4. Overall vulnerability indices of slum neighbourhoods' in question.

(a)

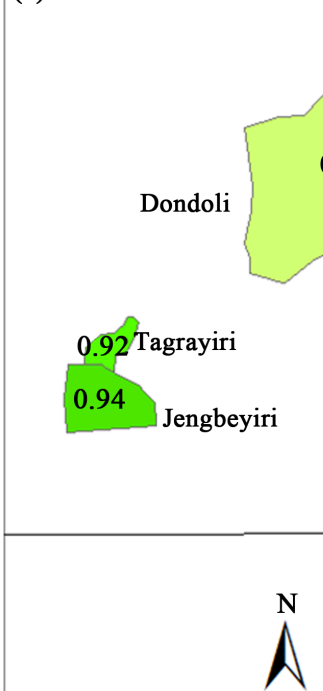

(b)

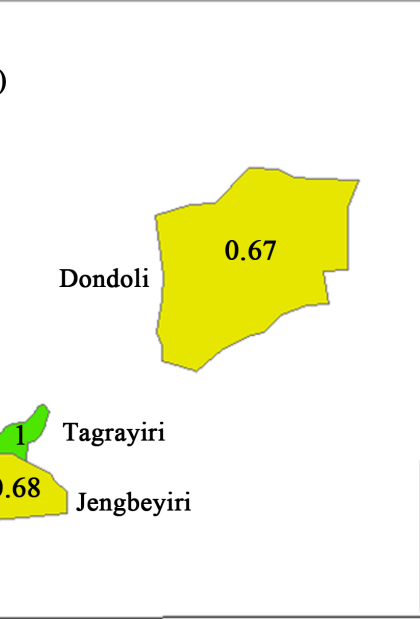

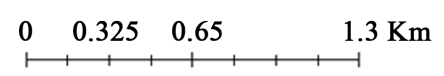

(c)

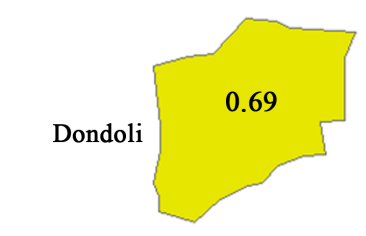

0.72 Tagrayiri

0.49

Jengbeyiri

Figure 5. Vulnerability indices of slum neighbourhoods in relation to sustainability dimensions. (a) Environmental vulnerability index; (b) Economic vulnerability index; (c) Social vulnerability index. 
Table 3. Effects of each of the three slum neighbourhoods in relation to 10 livelihood criteria.

\begin{tabular}{|c|c|c|c|c|c|c|}
\hline \multirow{2}{*}{ Dimensions } & \multirow{2}{*}{ Criteria } & \multirow{2}{*}{ Indicators/measurement } & \multicolumn{3}{|c|}{ Neighbourhoods and Effects } & \multirow{2}{*}{$\begin{array}{l}\text { Standard } \\
\text { Deviation }\end{array}$} \\
\hline & & & Dondoli & Tagrayiri & Jengbayiri & \\
\hline \multirow{2}{*}{ Economic } & Income & Average monthly household Income (US\$) & 105.71 & 122.86 & 80 & 21.6 \\
\hline & Consumption & Average monthly household Expenditure (US\$) & 34.29 & 72.86 & 51.43 & 19.3 \\
\hline \multirow{2}{*}{ Social } & Literacy & $\%$ that can read and write & $18 \%$ & $48 \%$ & $34 \%$ & 15.0 \\
\hline & Service availability & Centrality Index (see Table 4) & 1,583 & 683 & 433 & 604.8 \\
\hline \multirow{6}{*}{ Environment } & Water & $\%$ of households with pipe connection & $68 \%$ & $62 \%$ & $68 \%$ & 3.5 \\
\hline & Bath house & $\%$ of households with private bath & $39 \%$ & $44 \%$ & $36 \%$ & 4.0 \\
\hline & Toilet facility & $\%$ of households with private toilets & $15 \%$ & $14 \%$ & $18 \%$ & 2.1 \\
\hline & Living space & Average Household size & 6 & 5 & 6 & 0.6 \\
\hline & Housing durability & $\%$ housing in temporary structures & $37 \%$ & $34 \%$ & $29 \%$ & 4.0 \\
\hline & Refuse disposal & $\%$ of households with containers & $79 \%$ & $86 \%$ & $83 \%$ & 3.5 \\
\hline
\end{tabular}

\section{Table 4. Scalogram analysis.}

\begin{tabular}{|c|c|c|c|c|c|c|c|c|c|c|c|c|c|c|c|c|c|c|c|c|c|c|c|c|}
\hline 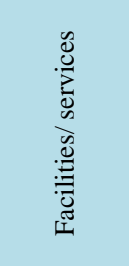 & & $\begin{array}{l}\vec{D} \\
心 \\
\vdots \\
\vdots\end{array}$ & 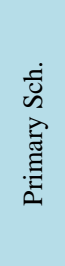 & 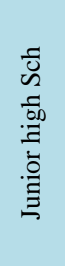 & 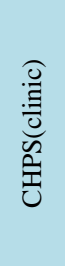 & 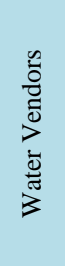 & $\frac{n}{\bar{z}}$ & 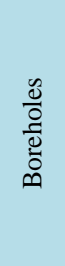 & 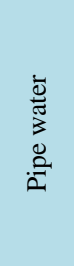 & 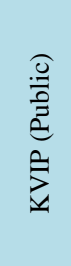 & 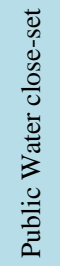 & 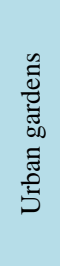 & 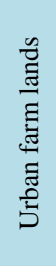 & 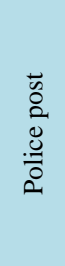 & 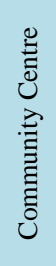 & $\begin{array}{l}\text {.0 } \\
\text { 莕 } \\
\text { D. } \\
0 \\
0 \\
0\end{array}$ & 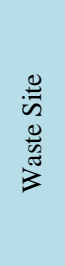 & 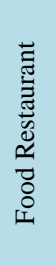 & 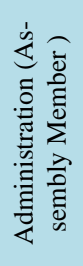 & 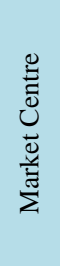 & 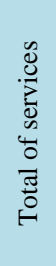 & 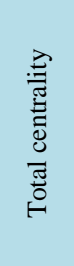 & 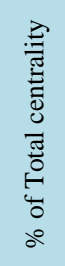 & 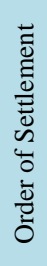 \\
\hline \multicolumn{2}{|c|}{ Weight } & \multirow{2}{*}{1} & \multirow{2}{*}{2} & \multirow{2}{*}{3} & \multirow{2}{*}{1} & \multirow{2}{*}{1} & \multirow{2}{*}{2} & \multirow{2}{*}{3} & \multirow{2}{*}{4} & \multirow{2}{*}{1} & \multirow{2}{*}{2} & \multirow{2}{*}{1} & \multirow{2}{*}{2} & \multirow{2}{*}{1} & \multirow{2}{*}{1} & \multirow{2}{*}{1} & \multirow{2}{*}{1} & \multirow{2}{*}{1} & \multirow{2}{*}{1} & \multirow{2}{*}{1} & & & & \\
\hline Settlement & Pop. & & & & & & & & & & & & & & & & & & & & & & & \\
\hline Dondoli & 2062 & $\checkmark$ & $\checkmark$ & $\checkmark$ & $\checkmark$ & $\checkmark$ & $\checkmark$ & $\checkmark$ & $\checkmark$ & $\checkmark$ & $X$ & $\checkmark$ & $\checkmark$ & $\mathbf{X}$ & $\mathbf{X}$ & $\checkmark$ & $\checkmark$ & $\checkmark$ & $\checkmark$ & $\checkmark$ & 16 & 1583 & 33.5 & 1 \\
\hline Jengbayiri & 1531 & $\mathbf{X}$ & $\mathbf{X}$ & $\mathbf{X}$ & $\checkmark$ & $\checkmark$ & $\checkmark$ & $\checkmark$ & $\checkmark$ & $\checkmark$ & $\mathbf{X}$ & $\mathbf{X}$ & $\mathbf{X}$ & $\mathbf{X}$ & $\checkmark$ & $\checkmark$ & $\checkmark$ & $\checkmark$ & $\checkmark$ & $\mathbf{X}$ & 11 & 683 & 3.3 & 2 \\
\hline Tagirayiri & 1586 & $\mathbf{X}$ & $\mathbf{X}$ & $\mathbf{X}$ & $\mathbf{X}$ & $\checkmark$ & $\checkmark$ & $\checkmark$ & $\checkmark$ & $\checkmark$ & $\mathbf{X}$ & $\mathbf{X}$ & $\mathbf{X}$ & $\mathbf{X}$ & $\mathbf{X}$ & $\mathbf{X}$ & $\checkmark$ & $\mathbf{X}$ & $\checkmark$ & $\mathbf{X}$ & 7 & 433 & 5.1 & 3 \\
\hline Frequency & & 1 & 1 & 1 & 2 & 3 & 3 & 3 & 3 & 3 & 0 & 1 & 1 & 0 & 1 & 2 & 3 & 2 & 3 & 1 & & & & \\
\hline Centrality & & 100 & 100 & 100 & 100 & 100 & 100 & 100 & 100 & 100 & 100 & 100 & 100 & 100 & 100 & 100 & 100 & 100 & 100 & 100 & & & & \\
\hline WCI & & 100 & 200 & 300 & 50 & 33.3 & 66.7 & 100 & 133.3 & 33.3 & - & 100 & 200 & - & 100 & 50 & 33.3 & 50 & 33.3 & 100 & TO' & TAL: & 2699 & \\
\hline
\end{tabular}

"I have changed my business three times in the last two and a half years. I used to sell secondhand clothing, and later changed to vegetables and now I am into bread selling. I have moved from these businesses due to changes in seasonal demands induced by our environment" (A respondent, 24-11-2014).

A cross classification of gender of household headship against the coping strategies show that more female headed households save more and rely less on constant diversifications. There is more fragility in the study areas given time given that about 151 households report "often" in the use of a particular strategy. In all the selected areas, autonomous coping strategies are higher than access to planned adaption by local government and NGOs. Whereas many (50\%) are members of political party ba6sed groups, interventions are given on individual bases. There is also more dependence on remittance in Dondoli than other selected areas. The results show that there are significant variations among slum neighbourhoods located within the same inner city with similar environmental conditions. This confirms the diversity in slums as reported in other studies (e.g. Boyagoda, 2014). From this study, the variations are because of differences in availability and access to social services, access to land, linkage with political structures and social networks.

\section{Discussion}

Though this study shows that, in terms of non-climatic environmental factors, the selected areas are not generally vulnerable, the existence of poor access to improved sanitation, inadequate access to potable water and congestion in rooms make the areas vulnerable to climate sensitive diseases. Through a lens of semi-aridity, slum 
dwellers in such areas are at high risk given that climate change is one of the major determinants of the incidence of climate-sensitive diseases. A large proportion (50\%) of Ghana's health burden is caused by climate-sensitive diseases such a meningitis, diarrhoea and malaria in northern Ghana (UNDP, 2010) where the landscape generally is arid or semi-arid. Research on slums should be contextualised in terms of socioeconomic and environmental realities other than generalised indicators of slums. Using diverse socioeconomic and environmental indicators could help understand the important factors in designing any intervention. It also shows where interventions must first be targeted. For example, the study shows that social and economic vulnerabilities must first be addressed before environmental vulnerabilities for these selected places.

The limited access to planned intervention reflects two important gaps. Firstly, the lack of urban focus in semi arid regions in terms of vulnerability research, limited intervention by city authorities and planning. Secondly, it also shows the governance failures in addressing urban challenges in semi arid regions. Whereas, the Upper West Region of Ghana is noted to have many NGOs addressing different vulnerabilities, their presence in terms of planned intervention is not felt in the urban setting. Planned intervention could serve as a platform for engagement among different governance actors. However, limited planned intervention reduces the realm of urban governance in the semi arid region. The issue of governance failure, as a key challenge to the mergence and perpetuation of vulnerabilities, is noted by other studies (Cheru, 2005; Bolay, 2006; Firdaus, 2012).

That notwithstanding, there are also much diversity among and within slum neighbourhoods in terms of use of coping strategies. The proportion of unskilled (22\%) does not have the capacity to afford training without access to planned intervention. With the broader skill, literacy and higher rate of diversification of livelihoods activities of some slum neighbourhoods, we argue that the major barriers are limited opportunities in labour markets, access to planned intervention and adversaries of their environment. The argument seeks to support STWR's (2010) opinion that slum dwellers are not actually a burden on urban population. In other perspectives, slums could be dynamic resources and source of urban resilience given the level of diversity in skills within and among neighbourhoods. Since the climate variability in semi-arid regions cannot be changed within a short time, efficiency of localised skills could be a focal point in addressing the vulnerability of slum dwellers. The nature of Wa Township's environment makes livelihood strategies more on nature of gamble than of calculated expectations (Wilks, 1989). As a necessity for survival, slum dwellers in semi-arid areas, considered under this study, have entrepreneurial spirits to address the challenges of their environment.

The findings confirm other studies in Latin America (Arias \& Palloni, 2006) and in Africa (Masinde, 2014; Koster, 2008) where the role of female household headship has significance in poverty reduction. The results also falls within the ongoing discourse of feminisation of poverty and household headship by empirically reporting the contrary-female-headed households are not the poorest of the poor as represented by others (e.g. Chant, 1997). The results further suggest that development interventions in slums of semi-arid areas of Ghana should not only target female-headed households, but male-headed households as well who are increasingly becoming vulnerable and poor. For example, after the Rwanda genocide, land and livestock were distributed to only female-headed households by relief agencies (Koster, 2008). Gendering the political economy of urbanisation in semi-arid regions could put limitations in a lens in which poverty and vulnerability can be addressed given that both male and female-headed households have dependants who are exposed to similar environmental conditions. Recognising the diversity within the rich-poor continuum of heads of households, there is no need to have a separate policy intervention for only female or male-headed households.

In the semi-arid region and per this study, we expect a radical difference from the existing space-based narrative (urban upgrading), which for years has been advocated and implemented in other slums. The existing narrative focused extremely on infrastructural fix as a solution to the predicaments of slum dwellers given that most case interventions are blind to the spatial context (Pugalis et al., 2014). This could only be fairly beneficial to slum dwellers in semi-arid regions under the environmental conditions within which they live. In this vein, the IPCC (2012) cautioned the need to adapt urban infrastructure to localised extreme climatic events. Existing measure of sustainability in slum upgrading focuses extremely on continuity of projects (Imparato \& Ruster, 2003) and hardly integrates local environmental conditions such as temperature and rainfall. A move away from "area-based" towards "place" could give temporal dimension to planned and autonomous interventions. Even under the purview, due consideration must be given to local realities and the participation of minorities as Bulkeley and Broto (2013) found that purposive climate change interventions in global cities create new forms of political space through technical interventions. 


\section{Conclusion}

The paper addresses the vulnerability context and coping strategies of slum dwellers in semi-arid environments. It shows that there is a surge in female-headed households in the study area attributable to the place-based context, such as religion and culture. Many households have a wider range of livelihood activities to cope with the adversaries of their environment. Many households have placed attachment to their environment for over 16 years and their coping strategies are driven by autonomous interventions other than planned interventions. There are also diversities within the neighbourhoods studied in terms of literacy, income, expenditure, headship, skills, coping strategies and availability of social services attributable to existing inequalities in opportunities. Slums are always branded as problematic other than an opportunity to utilise these diversities. The state of the World Cities Report 2012/2013 adopted city prosperity as an essential and necessary concept to urban development urban dwellers pursue satisfaction, maximize utility, and happiness (UN-Habitat, 2012). However, in the midst of vulnerabilities in semi-arid slums, the adversaries of the environment challenge the successful flourishing and thriving conditions. These observations suggest that the identification of place-based capabilities, opportunities and localised constraints could serve as basis for designing of an appropriate planned intervention. People-based and placed-based strategies should be the leading approaches to designing interventions in slum neighbourhoods of semi-arid regions as they are locally tailored and endogenous. The vulnerabilities of semi-arid cities require transforming urban livelihoods through sustained innovative place-based urban development strategies. This study has been able to show that, even among slum neighbourhoods, the overall degree of vulnerability varies which represent a dynamic resource for urban resilience. For planning purposes, area-based analysis of slum neighbourhoods can help in the identification of highly vulnerable areas for interventions. However, improving urban resilience and sustainability requires a system approach to the three dimensions of vulnerability assessed. From the selected cases, the sustainability challenge has to do with the social and economic dimensions rather than environmental concerns. Due consideration must be given to the provision of socioeconomic opportunities through planned interventions. The sustainability challenges therefore lies within the improvement of social and economic choices.

\section{References}

Ahmed, A. (2014). Ghana National Urban Policy and the Challenges for Slum and Urban Management. Unpublished Manuscript, Wa, Ghana: Wa Municipal Assembly.

Ajibade, I., \& McBean, G. (2014). Climate Extremes and Housing Rights: A Political Ecology of Impacts, Early Warning and Adaptation Constraints in Lagos Slum Communities. Geoforum, 55, 76-86. http://dx.doi.org/10.1016/j.geoforum.2014.05.005

Akter, T. (2008). Migration and Living Conditions in Urban Slums: Implications for Food Security. Cambridge: Cambridge University Press.

Alberti, M., Booth, D., Hill, K., Coburn, B., Avolio, C., Coe, S., \& Spirandelli, D. (2007). The Impact of Urban Patterns on Aquatic Ecosystems: An Empirical Analysis in Puget Lowland Sub-Basins. Landscape and Urban Planning, 80, $345-361$. http://dx.doi.org/10.1016/j.landurbplan.2006.08.001

Alemayehu, E. Y. (2008). Revisiting Slums, Revealing Responses: Urban Upgrading in Tenant-Dominated Inner-City Settlements in Addis Ababa, Ethiopia. Oslo: Norwegian University of Science and Technology, Faculty of Architecture and Fine Art, Department of Urban Design and Planning.

Ali, M. A., \& Toran, K. (2004). Migration, Slums and Urban Squalor-A Case Study of Gandhinagar Slum. In Proceedings of the Third International Conference on Environment and Health: Urban Planning and Environmental Management for Human Health (pp. 1-10). Bangalore: Karnataka Environment Research Foundation.

Angotti, T. (2006). Apocalyptic Anti-Urbanism. International Journal of Urban and Regional Research, 30, 961-967. http://dx.doi.org/10.1111/j.1468-2427.2006.00705.x

Annez, P., Buckley, R., \& Kalarickal, J. (2010). African Urbanization as Flight? Some Policy Implications of Geography. Urban Forum, 21, 221-234. http://dx.doi.org/10.1007/s12132-010-9085-6

Appeaning, A. K., (2013). Assessing Coastal Vulnerability Index to Climate Change: The Case of Accra—Ghana. Journal of Coastal Research, Special Issue, 65, 1892-1897.

Arias, E., \& Palloni, A. (2006). Prevalence and Patterns of Female-Headed Households in Latin America. CDE Working Paper No. 96-14. Madison: University of Wisconsin.

Arimah, B. (2011). Slums as Expressions of Social Exclusion: Explaining the Prevalence of Slums in African Countries. Proceedings of the International Conference on Social Cohesion and Development, Paris, 20-21 January 2011, 1-16. 
Bashiru, A. M. (2012). Sexual Violence against Women and Their Human Rights in the Wa Municipality in the Upper West Region of Ghana. Master's Thesis, Hague: Institute of Social Studies.

Berger, T. (2006). Slum Areas and Insecure Tenure in Urban Sub-Saharan Africa: A Conceptual Review of African Best Practices. Rotterdam: Institute of Housing and Urban Research, UPPSALA.

Berhanu, W., Colman, D., \& Fayissa, B. (2007). Diversification and Livelihood Sustainability in a Semi-Arid Environment: A Case Study from Southern Ethiopia. Journal of Development Studies, 43, 871-889. http://dx.doi.org/10.1080/00220380701384554

Biamah, E. K. (2005). Coping with Drought: Options for Soil and Water Management in Semi-Arid Kenya. PhD Thesis, Wageningen: Wageningen University and Research Centre.

Biederlack, L., \& Rivers, J. (2009). Comprehensive Food Security and Vulnerability Analysis (CFSVA) Ghana. Rome: United Nations World Food Programme.

Bird, K., \& Shepherd, A. (2003). Livelihoods and Chronic Poverty in Semi-Arid Zimbabwe. World Development, 31, 591610. http://dx.doi.org/10.1016/S0305-750X(02)00220-6

Bolay, J. (2006). Slums and Urban Development: Questions on Society and Globalisation. The European Journal of Development Research, 18, 284-298. http://dx.doi.org/10.1080/09578810600709492

Boyagoda, A., \& Suramya, A. M. K. (2014). Heterogeneity and Female-Headed Households in Sri Lanka: Vulnerability and Resilience in a Transitional Development Society. PhD Thesis, Hamilton, New Zealand: University of Waikato.

Bulkeley, H., \& Broto, V. C. (2013). Government by Experiment? Global Cities and the Governing of Climate Change. Transactions of the Institute of British Geographers, 38, 361-375. http://dx.doi.org/10.1111/j.1475-5661.2012.00535.X

Butala, M. N., Van Rooyen, M. J., \& Patel, R. B. (2010). Improved Health Outcomes in Urban Slums through Infrastructure Upgrading. Social Science \& Medicine, 71, 935-940. http://dx.doi.org/10.1016/j.socscimed.2010.05.037

Chant, S. (1997). Women-Headed Households: Poorest of the Poor? Perspectives from Mexico, Costa Rica and the Philippines. IDS Bulletin, 28, 26-48. http://dx.doi.org/10.1111/j.1759-5436.1997.mp28003003.x

Cheru, F. (2005). Globalization and Uneven Development in Africa: The Limits to Effective Urban Governance in the Provision of Basic Services. http://www.globalization-africa.org/papers/57.pdf

Choguill, C. L. (2007). The Search for Policies to Support Sustainable Housing. Habitat International, 31, $143-149$. http://dx.doi.org/10.1016/j.habitatint.2006.12.001

Clark, D. (2003). Urban World/Global City (2nd ed.). London: Rutledge.

Cruz, T. (2005). Stirling Memorial Lecture on Border Postcards: Chronicles from the Edge. http://www.cca.qc.ca/en/educationand-events/259-teddy-cruz-borderpostcards-chronicles-from-the-edge

d’Cruz, C., \& Satterthwaite, D. (2005). Building Homes, Changing Official Approaches: The Work of Urban Poor Organizations and Their Federations and Their Contributions to Meeting the Millennium Development Goals in Urban Areas. Paper Developed from a Background Report for the Millennium Project's Taskforce on Improving the Lives of Slum Dwellers, Human Settlement Programme, Nairobi: UN-HABITAT.

Davis, M. (2004). Planet of Slums: Urban Involution and the Informal Proletariat. New Left Review, 26, 5-34.

Davis, M. (2006). Planet of Slums. New York: Verso.

de Noronha, T., \& Vaz, E. (2015). Framing Urban Habitats: The Small and Medium Towns in the Peripheries. Habitat International, 45, 147-155. http://dx.doi.org/10.1016/j.habitatint.2014.06.025

Deelstra, T., \& Girardet, H. (2000). Urban Agriculture and Sustainable Cities. In N. Bakker, M. Dubbeling, S. Gundel, U. Sabel-Koshella, \& H. de Zeeuw (Eds.), Growing Cities, Growing Food: Urban Agriculture on the Policy Agenda (pp. 43-66). Feldafing: ZEL.

Dennis, R. (2004). Slums. In S. Harrison, S. Pile, \& N. Thrift (Eds.), Patterned Ground: Entanglements of Nature and Culture (pp. 21-38). London: Reaktion Books.

Desai, A. R., \& Devadas, S. P. (Eds.) (1990). Slum and Urbanization. London: Sangnam Books Limited.

Desai, P. (2008). Creating Low Carbon Communities: One Planet Living Solutions. Globalizations, 5, 67-71. http://dx.doi.org/10.1080/14747730701587462

Dickson, K. B., \& Benneh, G. (1988). A New Geography of Ghana. London: Longman Group.

Duadze, S. E. K. (2004). Land Use and Land Cover Study of the Savannah Ecosystem in the Upper West Region (Ghana) Using Remote Sensing. Ecology and Development Series, 16, 82-83.

Essamuah, M., \& Tonah, S. (2004). Coping with Urban Poverty in Ghana: An Analysis of Household and Individual Livelihood Strategies in Nima/Accra. Legon Journal of Sociology, 1, 79-96. 
Faguet, J. P. (2012). Decentralization and Popular Democracy: Governance from Below in Bolivia. Ann Arbor: University of Michigan Press.

Firdaus, G. (2012). Urbanization, Emerging Slums and Increasing Health Problems: A Challenge before the Nation: An Empirical Study with Reference to State of Uttar Pradesh in India. Journal of Environmental Research and Management, 3, 146-152.

Fox, S. (2014). The Political Economy of Slums: Theory and Evidence from Sub-Saharan Africa. World Development, 54, 191-203. http://dx.doi.org/10.1016/j.worlddev.2013.08.005

Freire-Medeiros, B. (2009). The Favela and Its Touristic Transits. Geoforum, 40, 580-588. http://dx.doi.org/10.1016/j.geoforum.2008.10.007

Friedman, L. (1968). Government and Slum Housing: A Century of Frustration. Chicago, IL: Rand McNally.

Frost, P., Campbell, B., Luckert, M., Mutamba, M., Mandondo, A., \& Kozanayi, W., (2007). In Search of Improved Rural Livelihoods in Semi-Arid Regions through Local Management of Natural Resources: Lessons from Case Studies in Zimbabwe. World Development, 35, 1961-1974. http://dx.doi.org/10.1016/j.worlddev.2006.11.012

Ghana Statistical Service (2012). 2010 Population and Housing Census. Accra: Ghana Statistical Service.

Ghana Statistical Service (2013). 2010 Population and Housing Census Report: Non-Monetary Poverty in Ghana. Accra: Ghana Statistical Service.

Ghana (2012). National Urban Policy. Accra: Ministry of Local Government and Rural Development.

Grimm, N. B., Faeth, S. H., Golubiewski, N. E., Redman, C. L., Wu, J., \& Bai, X. (2008). Global Change and the Ecology of Cities. Science, 319, 756-760. http://dx.doi.org/10.1126/science.1150195

Gulyani, S., \& Talukdar, D. (2008). Inside Informality: The Links between Poverty, Microenterprises and Living Conditions in Nairobi’s Slums. World Development, 38, 1710-1726. http://dx.doi.org/10.1016/j.worlddev.2010.06.013

Harvey, D. (2005). A Brief History of Neoliberalism. New York: Oxford University Press.

Harvey, D. (2008). The Right to the City. New Left Review, 53, 23-40.

Imparato, I., \& Ruster, F. (2003). Slum Upgrading and Participation: Lessons from Latin America. Washington DC: World Bank. http://dx.doi.org/10.1596/0-8213-5370-5

IPCC (2012). Managing the Risks of Extreme Events and Disasters to Advance Climate Change Adaptation. http://www.ipcc-wg2.gov/SREX/

Johnston, R. J., Gregory, D., Pratt, G., \& Watts, M. (2000). The Dictionary of Human Geography (4th ed.). Oxford: Blackwell Publishers Limited.

Jones, C., Leishman, C., \& MacDonald, C. (2009). Sustainable Urban Form and Residential Development Viability. Environment and Planning A, 41, 1667-1690. http://dx.doi.org/10.1068/a40265

Khalifa, M. A. (2011). Redefining Slums in Egypt: Unplanned versus Unsafe Areas. Habitat International, 35, 40-49. http://dx.doi.org/10.1016/j.habitatint.2010.03.004

Konadu-Agyemang, K. (2001). Structural Adjustment Programs and Housing Affordability in Accra, Ghana. The Canadian Geographer, 45, 528-544. http://dx.doi.org/10.1111/j.1541-0064.2001.tb01500.x

Koster, M. (2008). Linking Poverty and Household Headship in Post-Genocide Rwanda. Paper Selected for Presentation at the HiCN's Fourth Annual Workshop at Yale University, New Haven.

Lange, M. K. (2004). British Colonial Legacies and Political Development. World Development, 32, 905-922. http://dx.doi.org/10.1016/j.worlddev.2003.12.001

Lefebvre, H. (1996). Writings on Cities. London: Blackwell.

Lemma, T. (2005). A Comparison of Methodologies for Monitoring Slum Conditions within the Millennium Development Goals: The Case Study of Addis Ababa, Ethiopia. Master's Thesis, Enschede: International Institute for Geo-Information Science and Earth Observation.

Lioubimtseva, E., \& Henebry, G. M. (2009). Climate and Environmental Change in Arid Central Asia: Impacts, Vulnerability, and Adaptations. Journal of Arid Environments, 73, 963-977. http://dx.doi.org/10.1016/j.jaridenv.2009.04.022

Lioubimtseva, E., Cole, R., Adams, J. M., \& Kapustin, G. (2005). Impacts of Climate and Land-Cover Changes in Arid Lands of Central Asia. Journal of Arid Environments, 62, 285-308. http://dx.doi.org/10.1016/j.jaridenv.2004.11.005

Lucas Jr., R. E. (2004). Life Earnings and Rural-Urban Migration. Journal of Political Economy, 112, S29-S59. http://dx.doi.org/10.1086/379942

Mahama, C., \& Adarkwah, A. (2006). Land and Property Markets in Ghana. London: RICS.

Masinde, G. V. (2014). Food Security Coping Strategies in Female and Male Headed Households in Kenyan Slums: The Case of Kawangware, Nairobi. International Journal of Social Sciences and Entrepreneurship, 1, 36-54. 
Nsiah-Gyabaah, K. (2009). The Urban Housing Challenge and Prospects for Meeting the Housing Needs of the Urban Poor in Ghana. In CSIR/GIA (Eds.), Proceedings of the 2009 National Housing Conference (pp. 15-21). Accra: African Union for Housing Finance.

Nuttall, S., \& Mbembe, A. (2005). A Blasé Attitude: A Response to Michael Watts. Public Culture, 17, $193-201$. http://dx.doi.org/10.1215/08992363-17-1-193

Nyantakyi-Frimpong, H., \& Bezner K. R. (2014). A Political Ecology of High-Input Agriculture in Northern Ghana. Africa Geographic Review, 34, 13-35.

Nyantakyi-Frimpong, H., \& Bezner, K. R. (2015). The Relative Importance of Climate Change in the Context of Multiple Stressors in Semi-Arid Ghana. Global Environmental Change, 32, 40-56. http://dx.doi.org/10.1016/j.gloenvcha.2015.03.003

Obudho, R. A., \& Aduwo, G. O. (1989). Slum and Squatter Settlements in Urban Centres of Kenya: Towards a Planning Strategy. Journal of Housing and the Built Environment, 4, 17-30. http://dx.doi.org/10.1007/BF02498028

Ong, A. (2006). Neoliberalism as Exception: Mutations in Citizenship and Sovereignty. Durham: Duke University Press. http://dx.doi.org/10.1215/9780822387879

Owusu, G. (2008). Indigenes’ and Migrants Access to Land in Peri-Urban Areas of Ghana’s Largest City of Accra. International Development Planning Review, 30, 177-198. http://dx.doi.org/10.3828/idpr.30.2.5

Owusu, G. (2010). Social Effects of Poor Sanitation and Waste Management on Poor Urban Communities: A Neighbourhood-Specific Study of Sabon Zongo, Accra. Journal of Urbanism: International Research on Placemaking and Urban Sustainability, 3, 145-160. http://dx.doi.org/10.1080/17549175.2010.502001

Owusu, G., Agyei-Mensah, S., \& Lund, R. (2008). Slums of Hope and Slums of Despair: Mobility and Livelihoods in Nima, Accra. Norsk Geografisk Tidsskrift-Norwegian Journal of Geography, 62, 180-190. http://dx.doi.org/10.1080/00291950802335798

Pacione, M. (2005). Urban Geography: A Global Perspective. London: Routledge.

Pietro, G., Elliott D. S., \& Gabriella Y. C. (2005). A Home in the City: UN-Millennium Project Task Force Report on Improving the Lives of Slum Dwellers. New York: United Nations.

Prunty, J. (1998). Dublin Slums, 1800-1925: A Study of Urban Geography. Dublin: Irish Academic Press.

Pugalis, L., Giddings, B., \& Anyigor, A. (2014). Reappraising the World Bank Responses to Rapid Urbanisation: Slum Improvements in Nigeria. Local Economy, 29, 519-540. http://dx.doi.org/10.1177/0269094214541377

Rademacher-Schulz, C., Schraven, B., \& Mahama, E. S. (2014). Time Matters: Shifting Seasonal Migration in Northern Ghana in Response to Rainfall Variability and Food Insecurity. Climate and Development, 6, 46-52.

http://dx.doi.org/10.1080/17565529.2013.830955

Rain Watch (2014). Global Rain Fall Data. http://sharaku.eorc.jaxa.jp/GSMaP/guide.html

Roy, A. (2011). Slumdog Cities: Rethinking Subaltern Urbanism. International Journal of Urban and Regional Research, 35 , 223-238. http://dx.doi.org/10.1111/j.1468-2427.2011.01051.x

Scanlon, B. R., Keese, K. E., Flint, A. L., Flint, L. E., Gaye, C. B., Edmunds, W. M., \& Simmers, I. (2006). Global Synthesis of Groundwater Recharge in Semi-Arid and Arid Regions. Hydrological Processes, 20, 3335-3370. http://dx.doi.org/10.1002/hyp.6335

Seto, K. C., Guneralp, B., \& Hutyra, L. R. (2012). Global Forecasts of Urban Expansion to 2030 and Direct Impacts on Biodiversity and Carbon Pools. Proceedings of the National Academy of Sciences of the United States of America, 109, 16083-16088.

Sietchiping, R. K. (2005). Urban Geography: An Introductory Analysis. Oxford: Pergan Press.

Simone, A. M. (2004). For the City Yet to Come: Changing African life in Four Cities. Durham: Duke University Press. http://dx.doi.org/10.1215/9780822386247

Simone, A. M. (2010). City Life from Jakarta to Dakar: Movements at the Crossroads. New York: Routledge.

Slegers, M. F. W. (2008). If Only It Would Rain: Farmers’ Perceptions of Rainfall and Drought in Semi-Arid Central Tanzania. Journal of Arid Environments, 72, 2106-2123. http://dx.doi.org/10.1016/j.jaridenv.2008.06.011

Smith, N. (1996). The New Urban Frontier: Gentrification and the Revanchist City. New York: Routledge.

Songsore, J. (2003). Regional Development in Ghana: The Theory and the Reality. Accra: Woeli Publications.

Stokes, C. (1962). A Theory of Slums. Land Economics, 8, 187-197. http://dx.doi.org/10.2307/3144581

Stren, R., \& Halfani, M. (2001). The Cities of Sub-Saharan Africa: From Dependency to Marginality. In R. Paddison (Ed.), Handbook of Urban Studies (pp. 466-485). London: Sage Publications. http://dx.doi.org/10.4135/9781848608375.n29

STWR (2010). The Seven Myths of Slums: Challenging Popular Prejudices about the World's Urban Poor. London: Share the World's Resources. 
Thys, E., Oueadraog, M., Speybroec, N., \& Geerts, S. (2005). Socio-Economic Determinants of Urban Household Livestock Keeping in Semi-Arid Western Africa. Journal of Arid Environments, 63, 475-496. http://dx.doi.org/10.1016/j.jaridenv.2005.03.019

Tsegaye, D., Moe, S. R., \& Haile, M. (2009). Livestock Browsing, Not Water Limitations, Contributes to Recruitment Failure of Dobera Glabra in Semi Arid Ethiopia. Rangeland Ecology \& Management, 62, 540-549. http://dx.doi.org/10.2111/08-219.1

Tsegaye, D., Vedeld, P., \& Moe, S. R. (2013). Pastoralists and Livelihoods: A Case Study from Northern Afar, Ethiopia. Journal of Arid Environments, 91, 138-146. http://dx.doi.org/10.1016/j.jaridenv.2013.01.002

Ulrich, A., Speranza, C. I., Roden, P., Kiteme, B., Wiesmann, U., \& Nüsser, M. (2012). Small-Scale Farming in Semi-Arid Areas: Livelihood Dynamics between 1997 and 2010 in Laikipia, Kenya. Journal of Rural Studies, 28, 241-251. http://dx.doi.org/10.1016/j.jrurstud.2012.02.003

UNDP (2010). Integrating Climate Change into the Management of Priority Health Risks in Ghana: Environmental Finance Services. New York: UNDP.

UN-HABITAT (2003). The Challenge of Slums: Global Report on Human Settlements. London: Earthscan Publications Ltd.

UN-HABITAT (2009). State of the World's Cities: Harmonious Cities 2008/2009. London: Earthscan Publications.

UN-HABITAT (2012). State of the World's Cities 2012/2013. Nairobi: UN-HABITAT.

UN-HABITAT (2014). The State of African Cities 2014: Re-Imagining Sustainable Urban Transitions. Nairobi: UNHABITAT.

Walker, H. O. (1962). Weather and Climate in Ghana. In J. B. Wills, (Ed.), Agriculture and Land Use in Ghana (pp. 23-42). London: Oxford University Press.

Weisz, H., \& Steinberger, J. K. (2010). Reducing Energy and Material Flows in Cities. Current Opinion in Environmental Sustainability, 2, 185-192. http://dx.doi.org/10.1016/j.cosust.2010.05.010

Wilks, I. (1989). Wa and the Waala: Islam and Polity in North Western Ghana. Cambridge: Cambridge University Press.

Williams, K., Dair, C., \& Lindsay, M. (2010). Neighbourhood Design and Sustainable Lifestyles. In M. Jenks, \& C. Jones (Eds.), Dimensions of Sustainable City (pp. 183-214). New York: Springer.

World Bank (2009). World Development Report: Reshaping Economic Geography. Washington DC: The World Bank.

World Bank/UNCHS (2000). Cities Alliance for Cities without Slums: Action Plan for moving Slum Upgrading to Scale, Special Summary Edition. Washington DC: The World Bank.

Wu, J. (2009). Urban Sustainability: An Inevitable Goal of Landscape Research. Landscape Ecology, 25, 1-4. http://dx.doi.org/10.1007/s10980-009-9444-7

Yaro, J. A. (Ed.) (2013). Rural Development in Northern Ghana. New York: Nova Science Publishers. 